\title{
Using Physical Activity to Enhance Health Outcomes Across the Life Span
}

\author{
Dev Roychowdhury \\ DR ACADEMY, Melbourne, VIC 3000, Australia; info@drdevroy.com
}

Received: 28 November 2019; Accepted: 2 January 2020; Published: 4 January 2020

\begin{abstract}
Physical activity has been widely recognized as one of the primary determinants that proliferates positive psychophysiological health in individuals. Despite the numerous benefits of engaging in physical activity, a majority of the global population continues to be physically inactive or sedentary. The aim of this brief commentary is to capture the benefits of engaging in regular physical activity across the life span. In particular, this paper will highlight the benefits of engaging in regular physical activity with respect to age, gender, atypical populations, and lifestyle. Future research and recommendations have also been addressed.
\end{abstract}

Keywords: physical activity; health; life span; psychology; physiology; kinesiology

\section{Introduction}

Despite the well-established benefits of engaging in regular physical activity [1,2], recent trends have revealed that a large proportion of the global population is increasingly becoming sedentary [3,4], which has been associated with increased risks for several chronic conditions and mortality [5-7]. The global economic cost of physical inactivity has been conservatively estimated at $\$ 67.5$ billion [8,9] with no improvements in the levels of physical inactivity recorded in the past decade [10]. Understandably, the emotional and psychological burden are likely to be far reaching and horrid.

Physical activity has been defined as "any bodily movement produced by skeletal muscles that requires energy expenditure" [11]. The World Health Organization (WHO) has developed global recommendations on physical activity for health with the primary aim of guiding policy makers on the requisite amount of physical activity with respect to its frequency, duration, intensity, type, and total amount [12]. The recommendations that are set out address three age groups: 5-17 years old; 18-64 years old; and 65 years old and above [12]. It is primarily recommended that children and youth aged 5-17 years ought to engage in at least $60 \mathrm{~min}$ of moderate to vigorous intensity physical activity per day; adults aged 18-64 years ought to do at least 150 min of moderate intensity aerobic physical activity on a weekly basis or do at least 75 min of vigorous intensity aerobic physical activity in a week or an equivalent combination of moderate and vigorous intensity activity; and adults aged 65 years and above ought to do at least $150 \mathrm{~min}$ of moderate intensity aerobic physical activity in a week or do at least 75 min of vigorous intensity aerobic physical activity on a weekly basis or an equivalent combination of moderate and vigorous intensity activity [13].

Despite the clear practical recommendations that exist and explosion of research reporting on the benefits of engaging in regular physical activity, recent research now suggests that it is no longer sufficient to simply meet these recommendations to address health needs and lower health risks [14]. Furthermore, the conceptualization of the terms 'physical inactivity' and 'sedentary behaviour' has also been controversial $[15,16]$, which has implications for the way research protocols are designed and policy guidelines are formulated. Future research should, therefore, attempt to focus on arriving at a clear understanding of and consensus on what these terms constitute along with their theoretical, 
observational, and practical distinctions. For the purpose of this paper, the terms physical inactivity and sedentary behaviours are used interchangeably.

It is widely accepted that a range of factors affect individuals' involvement in physical activity, including psychological, social, environmental, and administrative factors [17]. Given the significance of different factors and the role they play in individuals' final decision to undertake and maintain regular physical activity [18], it is imperative to understand how motivational factors aid engagement in physical activity within such complex and multi-dimensional contexts. Research on participation motivation has clearly indicated that individuals' involvement in specific types of physical activity may be functionally characterized by the primary participation motives they have for engaging in those activities [19-21]. Although motivation research pertaining to physical activity has received substantial consideration, other determinants have received scant attention. The purpose of this brief commentary, therefore, is to encapsulate the benefits of engaging in regular physical activity across the life span. More specifically, this paper will highlight the benefits of engaging in regular physical activity with respect to age, gender, atypical populations, and lifestyle.

\section{Physical Activity across Age Groups}

Movement-based activity has been found to positively affect individuals' psychophysiology across different life stages. Physical activity has been linked to a number of adaptive psychological, physical, and social outcomes, especially in early childhood (i.e., birth to five years), including lower cardiovascular risk factors [22,23], improved bone development [24,25], decreased fat and body mass indices [26-29], improved motor development [30], and improved emotional, cognitive, and social development [31,32].

Research with school-aged children have also reported that physical activity may improve cognitive functioning and academic performance at school [33-39]. Physical activity has also been found to improve psychological health and prevent mental health conditions in young people [40,41]. Furthermore, recent neuroimaging research involving children has found that those who participated in a nine-month physical activity program showed reduction in fMRI brain activation in the right anterior prefrontal cortex and improvements in performance on a task of attentional and interference control when compared to the wait-list control group [42]. Similarly, movement-based learning environments have shown to improve children's executive functioning [43-45] and academic performance [46-53]. Studies have further reported that certain core executive functions, that appear to be activated through physical activity, are fundamental for children's psychophysiological and social development [54] and may play a vital role in their overall academic success [55-57].

Research on physical activity with adults has revealed that higher levels of physical activity are associated with better health-related quality of life [58-61]. Physically active adults are likely to have improved cardiovascular and metabolic health; better weight maintenance strategies; reduced risk of bone fracture and better bone mass and mineral density; increased muscular mass, strength, and power; and reduced risks of breast and colon cancer, diabetes, high blood pressure, coronary heart disease, stroke, hypertension, and depression [62-69].

Additionally, research on senescence has indicated that physical activity may play a vital protective role against the detrimental effects of age on psychological and physical health [70,71]. Higher physical activity in the elderly population has been linked to reduced prevalence of chronic conditions [72-75], decreased cognitive deterioration [76,77], improved physical health [74,78-80], better mental health $[78,81,82]$, reduced mortality rates [74,75,83-85], and improved quality of life $[78,81,82,86,87]$. Furthermore, age-related cross-sectional studies have indicated that physically fit older participants (as opposed to their sedentary counterparts) had comparable results to younger participants on a range of cognitive tasks, abilities, and processes [88-92]. Similarly, longitudinal studies have indicated that involvement in moderate and vigorous physical activity may buffer against cognitive degeneration in older age [93]. Finally, intervention studies reveal that older adults who 
participated in physical activity programs showed improved cardiorespiratory fitness [94,95], increased heart rate variability and enhanced executive control [96], and improved cognitive performance [97].

\section{Physical Activity and Gender}

It has been observed that there are systematic differences in the reasons males and females nominate for participating in physical activity [19-21]. Therefore, it is plausible to argue that gender differences exist in how individuals contrive and obtain benefits from engagement in specific physical activities, which may be functionally characterized by the benefits the activities seem to offer to those individuals. Despite this, recommended levels of physical activity around the world are more or less the same with minimal or no refinement related to gender [13].

Research has shown that males are more likely to be physically active across different life stages-through fetal and neonatal periods [98], infancy [99-101], childhood [102], adolescence [103], and adulthood $[19,104]$ - as compared to their female counterparts. According to some researchers, this tilts the physical activity research and practice domains in favour of males, with health professionals often overlooking the requirements of females [105]. This is further exacerbated by the fact that females generally tend to engage less in physical activity [106], males take part in more specific sedentary behaviours [107], gender socialization and roles differ from birth onwards [108], and specific psychological, social, and environmental factors vary across lifetime $[109,110]$, which play a significant role in mediating the relationship between gender and physical activity involvement.

Although it is known that males and females tend to favour different kinds of physical activities, it is important to understand how this participation and consequent health outcomes are affected. Research indicates that level, intensity, type, and amount of physical activity involvement may have different beneficial effects for males and females. For instance, Asztalos and colleagues found that males participating in higher levels and vigorous intensity physical activity had lowered feelings of psychological distress, and females engaging in walking and moderate intensity physical activity had better emotional well-being and regulation [111]. This has also been confirmed in other studies that purport that males benefit from engaging in vigorous physical activities [112-114] whereas females benefit from low to moderate intensity physical activities [115].

Furthermore, studies involving differential intensity physical activity and health conditions show clear gender differences in terms of health outcomes. For instance, studies in cardiovascular disease [115-118] and diabetes [119] indicate that females are more likely than males to benefit from low to moderate intensity physical activity. In another study involving physical activity and cancer prevention, risk reduction in colon cancer in females was related to increased leisure time activity, whereas risk reduction in males was related to both leisure and occupational physical activity [120].

Gender differences in exercise habits also reveal that, with higher levels of exercise, the level of reported self-esteem increases in males and decreases in females [121]. In contrast, it has also been found that females who engage in low intensity physical activity report higher self-esteem and quality of life as compared to females who participate in high intensity physical activity [122]. This may be attributed to the different motives males and females have for engaging in physical activities. For instance, research suggests that males are more likely to participate in physical activity due to social and competitive reasons, whereas females are more likely to engage in physical activity for appearance motives [19-21].

\section{Physical Activity across Atypical Population}

While research on physical activity has established clear benefits for the healthy population [11-13], recent research has demonstrated that physical activity may also have positive implications for atypical conditions and population. For instance, it has been found that physical activity may aid in preventing obesity by helping individuals increase their total energy expenditure, decrease total body fat, and even build muscle mass by engaging in muscle-strengthening activities [123]. Furthermore, physical activity has been recommended as an alternative disease management strategy for individuals living 
with immunodeficiencies [124,125]. Additionally, research in the domain of cancer prevention suggests that physical activity may reduce the risk of a range of malignancies, including lung, colon, breast, prostate, and endometrial cancer [120,126-132]. Similarly, risk modeling studies indicate that physical activity may help reduce the risk of recurrent stroke [133]. Studies in diabetes have also indicated that physical activity, especially aerobic activity, is associated with lower cardiovascular and mortality risks in both type 1 and type 2 diabetes [134]. Research in different types of physical activity has also confirmed that it may play a vital role in improving overall physical health, including cardiorespiratory, musculoskeletal, and neuromotor fitness [135].

In recent years, the positive effects of physical activity on mental health have also come to the fore [136-138]. Physical activity has been found to be particularly effective in ameliorating the effects of stress, anxiety, and depression [139]. Asmundson and colleagues found that physical activity had positive therapeutic effects on stress and stress-related symptoms [137]. Similarly, systematic reviews of physical activity, especially aerobic and anaerobic exercise, suggest physical activity to be an efficacious transdiagnostic intervention for anxiety-related disorders [140]. Furthermore, randomized control trials have also indicated physical activity to be an effective tool in reducing symptoms of depression [141].

In addition to its psychophysiological benefits, physical activity has also been found to be positively associated with subjective health outcomes, including personal experiences of self-esteem, health behaviours, fitness, life situation, and ill-health [142,143]. A range of studies have reported that higher levels of physical activity were positively associated with higher self-esteem in children, adolescents, and young and middle-aged adults [144-151]. Finally, researchers have also found that physical activity not only fosters emotional, social, and motor skills, it also promotes personal well-being and strengthens relations between peers [152].

\section{Physical Activity and Lifestyle}

An individual's capacity to undertake physical tasks of everyday living plays a vital role in their physical well-being and overall welfare. While higher physical functioning in individuals is associated with valued tasks and independent living, poor physical functioning has been found to be associated with poorer quality of life, inhibited social participation, and higher risk of death $[153,154]$. Other studies have also confirmed longitudinal and cross-sectional associations between physical functioning and physical activity [155].

Studies have indicated that physical functioning of individuals depends on a range of lifestyle and socio-economic factors and as such it is reasonable to believe that these factors may also play an important role in regulating involvement in physical activity. For instance, socio-economic status has been found to be one of the strongest predictors of physical functioning [156,157], with adults with lower socio-economic status found to be less likely to engage in healthy behaviours [158]. Furthermore, research indicates that higher levels of education, higher income, and living in affluent areas were positively associated with better physical functioning [159-163]. Additionally, a number of lifestyle-related behavioural risk factors, including smoking, excess alcohol consumption, and poor nutrition, have been found to negatively affect physical functioning [164-170].

\section{Discussion}

A review of the literature suggests that the benefits of engaging in regular physical activity has been consistently associated with a range of positive psychological and physical health outcomes for individuals across the life span. Research in the active living, sport, and exercise literature has reliably demonstrated that individuals may have different reasons for engaging in different forms of physical activities and as such may gain different benefits from engaging in those activities. For instance, it is vital for toddlers, pre-school, and school-aged children to engage in active play that fosters their movement, communication, confidence, social, and interaction skills. Therefore, in addition to the evident kinesiological benefits that they would obtain from engaging in physical activity, it would 
also be reasonable to state that while, on one hand, structured play can nurture their movement, intellectual, and problem-solving skills, unstructured play can also, on the other hand, cultivate their creative, imaginative, and social skills. Similarly, other studies have also indicated that older adults tend to engage in leisure time physical activities in order to relax, maintain independence, flexibility, and mobility, and reduce muscle atrophy, amongst other reasons. Despite this, majority of research in the sport and exercise domain has focused exclusively on the type, intensity, frequency, and/or amount of physical activity with no or very little regard given to the saliency of other influences which may play an equivale role in underscoring individuals' primary participation in those activities. Health professionals and policy makers should, therefore, focus on developing targeted interventions that not only accentuate physiological benefits in physical activity participation, but also emphasize on the motivational and enjoyable aspects of physical activity involvement with especial attention given to individual-activity fit. Designing novel and tailored evidence-based interventions specific to participants would ensure that those individuals engage in appropriate forms of physical activities, which would maximize satisfaction and reduce drop-out rates. Furthermore, creating smart and innovative campaigns will not only promote the uptake of physical activity, but will also aid professionals in understanding and addressing barriers in an effective and efficient manner.

Physical activity is a complex behaviour which often has personal, social, and public antecedents and consequences. Individuals may engage in physical activity in many ways, with multiple combinations of dose-responses, motives, contexts, and outcomes. It is, therefore, imperative to understand what constitutes physical activity engagement, how it is perceived by individuals, and how it gets manifested in everyday life. Future research in this domain must focus on ethnographic, narrative, intervention, and longitudinal studies to complement quantitative experiments in order to arrive at a comprehensive conceptualization of physical activity involvement along with its practical implications. This must also include how much physical activity is adequate, sufficient, or recommended for individuals with specific needs or goals.

Physical activity may also have varied meanings for different individuals depending on the context, lifestyle choices, religious and spiritual practices, and local customs and traditions, in which the activities are being carried out. Given the multivariate nature of physical activity, exploratory and cross-sectional studies ought to focus on social, linguistically-diverse, and communal components of physical activity involvement. This may, for instance, include school-based physical education programs, or slow body-movement intervention programs in aged care setting, or appropriate diet-exercise awareness campaigns to enable better decision-making in clients. Similarly, public health announcements, messages, and campaigns should be clear, updated regularly, and modernized.

Given the efficaciousness of physical activity across the life span, another area that would particularly benefit is the health care sector. There is an insistent need for researchers, practitioners, consultants, and policy makers to formulate a unified diagnostic and prescriptive code by incorporating physical activity across a variety of settings, whereby physicians could potentially counsel and recommend clients appropriate physical activity as part of their treatment plans to further therapeutic goals. This would not only help clients gain valuable kinesiological benefits but also address excessive dependence on medications that is prevalent across numerous health care settings and conditions. This also means that appropriate training and study modules must be incorporated in educational and professional settings to equip future practitioners with relevant and necessary skills and knowledge.

With the advent and excessive use of technology in everyday life, future research could also focus on utilizing mobile applications, web-based platforms, and virtual or augmented reality wearables to help individuals keep track of their physical activity goals, maintain adherence, and gain desired health outcomes. This could also be used to understand pertinent shifts in generational differences, social and community trends, and personal preferences. Finally, utilizing both traditional and novel methodologies may ultimately assist us in understanding why individuals engage in different forms of physical activity and the myriad benefits they could achieve from such engagement. This will undoubtedly have huge implications for the psychological and kinesiological health of individuals. 


\section{Conclusions}

In summary, it is now widely recognized that engagement in appropriate forms of physical activity may have numerous psychological, kinesiological, and social benefits. It has been noted in the literature that people tend to engage in diverse forms of physical activity for primary participation reasons by virtue of their age, gender, condition, and context. Understanding the influences of these variables and tailoring appropriate programs and interventions will greatly assist individuals maximize their physical activity needs and goals.

Funding: This research received no external funding.

Acknowledgments: I would like to thank the Journal Guest Editors of this special issue, Marianna Alesi and Sebastiano Costa, for inviting me to contribute this paper. I would also like to thank the Assistant Managing Editors, Molly Lu and Sydney Tang, for their assistance and administrative correspondences regarding this special journal issue.

Conflicts of Interest: The author declares no conflict of interest.

\section{References}

1. Frederick-Recascino, C.; Morris, T. Intrinsic and extrinsic motivation in sport and exercise. In Sport Psychology: Theory, Applications and Issues; Morris, T., Summers, J., Eds.; John Wiley \& Sons: Melbourne, Australia, 2004; pp. 121-151.

2. Lloyd-Jones, D.M.; Yuling, H.; Labarthe, D.; Mozaffarian, L.J.; Appel, L.; Van Horn, K. Defining and setting national goals for cardiovascular health promotion and disease reduction: The American Heart Association's strategic impact goal, through 2020 and beyond. Circulation 2010, 121, 586-613. [CrossRef] [PubMed]

3. Matthews, C.E.; Chen, K.Y.; Freedson, P.S.; Buchowski, M.S.; Beech, B.M.; Pate, R.R.; Troiano, R.P. Amount of time spent in sedentary behaviors in the United States, 2003-2004. Am. J. Epidemiol. 2008, 167, 875-881. [CrossRef] [PubMed]

4. Hansen, B.H.; Kolle, E.; Dyrstad, S.M.; Holme, I.; Anderssen, S.A. Accelerometer-determined physical activity in adults and older people. Med. Sci. Sports Exerc. 2012, 44, 266-272. [CrossRef] [PubMed]

5. Grøntved, A.; Hu, F.B. Television viewing and risk of type 2 diabetes, cardiovascular disease, and all-cause mortality: A meta-analysis. JAMA 2011, 305, 2448-2455. [CrossRef]

6. Chau, J.Y.; Grunseit, A.C.; Chey, T.; Stamatakis, E.; Brown, W.J.; Matthews, C.E.; Bauman, A.E.; van der Ploeg, H.P. Daily sitting time and all-cause mortality: A meta-analysis. PLoS ONE 2013, 8, 80000. [CrossRef]

7. Biswas, A.; Oh, P.I.; Faulkner, G.E.; Bajaj, R.R.; Silver, M.A.; Mitchell, M.S.; Alter, D.A. Sedentary time and its association with risk for disease incidence, mortality, and hospitalization in adults: A systematic review and meta-analysis. Ann. Intern. Med. 2015, 162, 123-132. [CrossRef]

8. Ding, D.; Lawson, K.D.; Kolbe-Alexander, T.L.; Finkelstein, E.A.; Katzmarzyk, P.T.; van Mechelen, W.; Pratt, M. The economic burden of physical inactivity: A global analysis of major non-communicable diseases. Lancet 2016, 388, 1311-1324. [CrossRef]

9. Torjesen, I. Global cost of physical inactivity is estimated at $\$ 67.5 \mathrm{bn}$ a year. BMJ 2016, 354, i4187. [CrossRef]

10. Prevalence of Insufficient Physical Activity. Available online: https:/www.who.int/gho/ncd/risk_factors/ physical_activity_text/en/ (accessed on 20 November 2019).

11. Physical Activity. Available online: https://www.who.int/dietphysicalactivity/pa/en/ (accessed on 20 November 2019).

12. Global Recommendations on Physical Activity for Health. Available online: https://www.who.int/ dietphysicalactivity/factsheet_recommendations/en/ (accessed on 20 November 2019).

13. Global Recommezndations on Physical Activity for Health. Available online: https://apps.who.int/iris/bitstream/ handle/10665/44399/9789241599979_eng.pdf;jsessionid=DE9AB06EE6639F7F13089681CD5D7298? sequence=1 (accessed on 20 November 2019).

14. González, K.; Fuentes, J.; Márquez, J.L. Physical inactivity, sedentary behavior and chronic diseases. Korean J. Fam. Med. 2017, 38, 111. [CrossRef]

15. Yates, T.; Wilmot, E.G.; Davies, M.J.; Gorely, T.; Edwardson, C.; Biddle, S.; Khunti, K. Sedentary behavior. Am. J. Prev. Med. 2011, 40, e33-e34. [CrossRef] 
16. Pate, R.R.; O’Neill, J.R.; Lobelo, F. The evolving definition of "sedentary". Exerc. Sport Sci. Rev. 2008, 36, 173-178. [CrossRef] [PubMed]

17. Biddle, S.J.; Mutrie, N. Psychology of Physical Activity: Determinants, Well-Being and Interventions; Routledge: London, UK, 2007.

18. Hoare, E.; Stavreski, B.; Jennings, G.; Kingwell, B. Exploring motivation and barriers to physical activity among active and inactive Australian adults. Sports 2017, 5, 47. [CrossRef] [PubMed]

19. Roychowdhury, D. Examining Reasons for Participation in Sport and Exercise Using the Physical Activity and Leisure Motivation Scale (PALMS). Ph.D. Thesis, Victoria University, Melbourne, Australia, 2012.

20. Roychowdhury, D. A comprehensive measure of participation motivation: Examining and validating the Physical Activity and Leisure Motivation Scale. J. Hum. Sport Exerc. 2018, 13, 231-247. [CrossRef]

21. Roychowdhury, D. Functional significance of participation motivation on physical activity involvement. Psychol. Thought 2018, 11, 9-17. [CrossRef]

22. Saakslahti, A.; Numminen, P.; Niinikoski, H.; Rask-Nissila, L.; Viikari, J.; Tuominen, J.; Välimäki, I. Is physical activity related to body size, fundamental motor skills, and CHD risk factors in early childhood? Pediatric Exerc. Sci. 1999, 11, 327-340. [CrossRef]

23. Sääkslahti, A.; Numminen, P.; Varstala, V.; Helenius, H.; Tammi, A.; Viikari, J.; Välimäki, I. Physical activity as a preventive measure for coronary heart disease risk factors in early childhood. Scand. J. Med. Sci. Sports 2004, 14, 143-149. [CrossRef] [PubMed]

24. Binkley, T.; Specker, B. Increased periosteal circumference remains present 12 months after an exercise intervention in preschool children. Bone 2004, 35, 1383-1388. [CrossRef]

25. Janz, K.F.; Burns, T.L.; Torner, J.C.; Levy, S.M.; Paulos, R.; Willing, M.C.; Warren, J.J. Physical activity and bone measures in young children: The Iowa bone development study. Pediatrics 2001, 107, 1387-1393. [CrossRef]

26. Metallinos-Katsaras, E.S.; Freedson, P.S.; Fulton, J.E.; Sherry, B. The association between an objective measure of physical activity and weight status in preschoolers. Obesity 2007, 15, 686-694. [CrossRef]

27. Trost, S.G.; Sirard, J.R.; Dowda, M.; Pfeiffer, K.A.; Pate, R.R. Physical activity in overweight and non-overweight preschool children. Int. J. Obes. Relat. Metab. Disord. 2003, 27, 834-839. [CrossRef]

28. Janz, K.F.; Levy, S.M.; Burns, T.L.; Torner, J.C.; Willing, M.C.; Warren, J.J. Fatness, physical activity, and television viewing in children during the adiposity rebound period: The Iowa bone development study. Prev. Med. 2002, 35, 563-571. [CrossRef] [PubMed]

29. Atkin, L.M.; Davies, P.S. Diet composition and body composition in preschool children. Am. J. Clin. Nutr. 2000, 72, 15-21. [CrossRef] [PubMed]

30. Cliff, D.P.; Okely, A.D.; Smith, L.M.; Kim, M. Relationships between fundamental movement skills and objectively measured physical activity in preschool children. Pediatric Exerc. Sci. 2009, 21, 436-449. [CrossRef] [PubMed]

31. Colwell, M.; Lindsey, E. Preschool children's pretend and physical play and sex of play partner: Connections to peer competence. Sex Roles 2005, 52, 497-509. [CrossRef]

32. Lindsey, E.W.; Colwell, M.J. Preschoolers' emotional competence: Links to pretend and physical play. Child Study J. 2003, 33, 39-52.

33. Tomporowski, P.; McCullick, B.; Pesce, C. Enhancing Children's Cognition with Physical Activity Games; Human Kinetics: Champaign, IL, USA, 2015.

34. Tomporowski, P.D.; McCullick, B.; Pendleton, D.M.; Pesce, C. Exercise and children's cognition: The role of exercise characteristics and a place for metacognition. J. Sport Health Sci. 2015, 4, 47-55. [CrossRef]

35. Khan, N.A.; Hillman, C.H. The relation of childhood physical activity and aerobic fitness to brain function and cognition: A review. Pediatric Exerc. Sci. 2014, 26, 138-146. [CrossRef]

36. Singh, A.; Uijtdewilligen, L.; Twisk, J.R.; van Mechelen, W.; Chinapaw, M.M. Physical activity and performance at school: A systematic review of the literature including a methodological quality assessment. Arch. Pediatrics Adolesc. Med. 2012, 166, 49-55. [CrossRef]

37. Álvarez-Bueno, C.; Pesce, C.; Cavero-Redondo, I.; Sánchez-López, M.; Garrido-Miguel, M.; Martínez-Vizcaíno, V. Academic achievement and physical activity: A meta-analysis. Pediatrics 2017, 140, e20171498. [CrossRef]

38. Santana, C.A.; Azevedo, L.B.; Cattuzzo, M.T.; Hill, J.O.; Andrade, L.P.; Prado, W.L. Physical fitness and academic performance in youth: A systematic review. Scand. J. Med. Sci. Sports 2017, 27, 579-603. [CrossRef]

39. Owen, K.B.; Parker, P.D.; Van Zanden, B.; MacMillan, F.; Astell-Burt, T.; Lonsdale, C. Physical activity and school engagement in youth: A systematic review and meta-analysis. Educ. Psychol. 2016, 51, 129-145. [CrossRef] 
40. Biddle, S.J.; Asare, M. Physical activity and mental health in children and adolescents: A review of reviews. Br. J. Sports Med. 2011, 45, 886-895. [CrossRef] [PubMed]

41. Babic, M.; Morgan, P.J.; Plotnikoff, R.C.; Lonsdale, C.; White, R.L.; Lubans, D.R. Physical activity and physical self-concept in youth: Systematic review and meta-analysis. Sports Med. 2014, 44, 1589-1601. [CrossRef] [PubMed]

42. Chaddock-Heyman, L.; Erickson, K.I.; Voss, M.; Knecht, A.; Pontifex, M.B.; Castelli, D.; Hillman, C.; Kramer, A. The effects of physical activity on functional MRI activation associated with cognitive control in children: A randomized controlled intervention. Front. Hum. Neurosci. 2013, 7, 1-13. [CrossRef]

43. Egger, F.; Conzelmann, A.; Schmidt, M. The effect of acute cognitively engaging physical activity breaks on children's executive functions: Too much of a good thing? Psychol. Sport Exerc. 2018, 36, 178-186. [CrossRef]

44. Schmidt, M.; Jäger, K.; Egger, F.; Roebers, C.M.; Conzelmann, A. Cognitively engaging chronic physical activity, but not aerobic exercise, affects executive functions in primary school children: A group-randomized controlled trial. J. Sport Exerc. Psychol. 2015, 37, 575-591. [CrossRef]

45. Hillman, C.H.; Pontifex, M.B.; Raine, L.B.; Castelli, D.M.; Hall, E.E.; Kramer, A.F. The effect of acute treadmill walking on cognitive control and academic achievement in preadolescent children. Neuroscience 2009, 159, 1044-1054. [CrossRef]

46. Mavilidi, M.F.; Okely, A.; Chandler, P.; Domazet, S.L.; Paas, F. Immediate and delayed effects of integrating physical activity into preschool children's learning of numeracy skills. J. Exp. Child Psychol. 2018, 166, 502-519. [CrossRef]

47. Mavilidi, M.F.; Ruiter, M.; Schmidt, M.; Okely, A.D.; Loyens, S.; Chandler, P.; Paas, F. A narrative review of school-based physical activity for enhancing cognition and learning: The importance of relevancy and integration. Front. Psychol. 2018, 9, 2079. [CrossRef]

48. Mavilidi, M.F.; Okely, A.D.; Chandler, P.; Cliff, D.P.; Paas, F. Effects of integrated physical exercises and gestures on preschool children's foreign language vocabulary learning. Educ. Psychol. Rev. 2015, 27, 413-426. [CrossRef]

49. Mavilidi, M.F.; Okely, A.D.; Chandler, P.; Paas, F. Effects of integrating physical activities into a science lesson on preschool children's learning and enjoyment. Mind Brain Educ. 2017, 31, 281-290. [CrossRef]

50. Mavilidi, M.F.; Okely, A.D.; Chandler, P.; Paas, F. Infusing physical activities into the classroom: Effects on preschool children's geography learning. Appl. Cogn. Psychol. 2016, 10, 256-263. [CrossRef]

51. Toumpaniari, K.; Loyens, S.; Mavilidi, M.F.; Paas, F. Preschool children's foreign language vocabulary learning by embodying words through physical activity and gesturing. Educ. Psychol. Rev. 2015, 27, 445-456. [CrossRef]

52. Riley, N.; Lubans, D.R.; Holmes, K.; Gore, J.; Hansen, V.; Morgan, P.J. Movement-based mathematics: Enjoyment and engagement without compromising learning through the EASY Minds program. Eurasia J. Math Sci. Technol. Educ. 2017, 13, 1653-1673. [CrossRef]

53. Riley, N.; Lubans, D.R.; Holmes, K.; Morgan, P.J. Findings from the EASY Minds cluster randomized controlled trial: Evaluation of a physical activity integration program for mathematics in primary schools. J. Phys. Act. Health 2016, 13, 198-206. [CrossRef]

54. Miyake, A.; Friedman, N.P.; Emerson, M.J.; Witzki, A.H.; Howerter, A.; Wager, T.D. The unity and diversity of executive functions and their contributions to complex "frontal lobe" tasks: A latent variable analysis. Cogn. Psychol. 2000, 41, 49-100. [CrossRef]

55. Schmidt, M.; Egger, F.; Benzing, V.; Jäger, K.; Conzelmann, A.; Roebers, C.M.; Pesce, C. Disentangling the relationship between children's motor ability, executive function and academic achievement. PLoS ONE 2017, 12, e0182845. [CrossRef]

56. Diamond, A. Executive functions. Annu. Rev. Psychol. 2013, 64, 135-168. [CrossRef]

57. Diamond, A.; Lee, K. Interventions shown to aid executive function development in children 4 to 12 years old. Science 2011, 333, 959-964. [CrossRef]

58. Anokye, N.K.; Trueman, P.; Green, C. Physical activity and health related quality of life. BMC Public Health 2012, 12, 624. [CrossRef]

59. Bize, R.; Johnson, J.A.; Plotnikoff, R.C. Physical activity level and health-related quality of life in the general adult population: A systematic review. Prev. Med. 2007, 45, 401-415. [CrossRef] [PubMed]

60. Vuillemin, A.; Boini, S.; Bertrais, S.; Tessier, S.; Oppert, J.M.; Hercber., S.; Guillemin, F.; Briançon, S. Leisure time physical activity and health-related quality of life. Prev. Med. 2005, 41, 562-569. [CrossRef] [PubMed] 
61. Wendel-Vos, G.; Schuit, A.; Tijhuis., M.; Kromhout, D. Leisure time physical activity and health-related quality of life: Cross-sectional and longitudinal associations. Qual. Life Res. 2004, 13, 667-677. [CrossRef] [PubMed]

62. Warburton, D.E.; Charlesworth, S.; Ivey, A.; Nettlefold, L.; Bredin, S.S. A systematic review of the evidence for Canada's physical activity guidelines for adults. Int. J. Behav. Nutr. Phys. Act. 2010, 7, 39. [CrossRef]

63. Physical Activity Guidelines Advisory Committee (PAGAC). Physical Activity Guidelines Advisory Committee Report; US Department of Health and Human Services: Washington, DC, USA, 2008.

64. Cook, I.; Alberts, M.; Lambert, E.V. Relationship between adiposity and pedometer-assessed ambulatory activity in adult, rural African women. Int. J. Obes. 2008, 32, 1327-1330. [CrossRef]

65. Nocon, M.; Hiemann, T.; Müller-Riemenschneider, F.; Thalau, F.; Roll, S.; Willich, S.N. Association of physical activity with all-cause and cardiovascular mortality: A systematic review and meta-analysis. Eur. J. Cardiovasc. Prev. Rehabil. 2008, 15, 239-246. [CrossRef]

66. Sofi, F.; Capalbo, A.; Cesari, F.; Abbate, R.; Gensini, G.F. Physical activity during leisure time and primary prevention of coronary heart disease: An updated meta-analysis of cohort studies. Eur. J. Cardiovasc. Prev. Rehabil. 2008, 15, 247-257. [CrossRef]

67. Warburton, D.; Katzmarzyk, P.T.; Rhodes, R.E.; Shephard, R.J. Evidence-informed physical activity guidelines for Canadian adults. Can. J. Public Health 2007, 98, S16-S68.

68. Bauman, A.; Lewicka, M.; Schöppe, S. The Health Benefits of Physical Activity in Developing Countries; World Health Organization: Geneva, Switzerland, 2005.

69. Steyn, K.; Sliwa, K.; Hawken, S.; Commerford, P.; Onen, C.; Damasceno, A.; Ounpuu, S.; Yusuf, S. Risk factors associated with myocardial infarction in Africa: The INTERHEART Africa study. Circulation 2005, 112, 3554-3561. [CrossRef]

70. Hertzog, C.; Kramer, A.F.; Wilson, R.S.; Lindenberger, U. Enrichment effects on adult cognitive development: Can the functional capacity of older adults be preserved and enhanced? Psychol. Sci. Public Interest 2008, 9, 1-65. [CrossRef]

71. Kramer, A.F.; Bherer, L.; Colcombe, S.J.; Dong, W.; Greenough, W.T. Environmental influences on cognitive and brain plasticity during aging. J. Gerontol. A Biol. Sci. Med. Sci. 2004, 59, 940-957. [CrossRef] [PubMed]

72. Soares-Miranda, L.; Siscovick, D.S.; Psaty, B.M.; Longstreth, W.T.; Mozaffarian, D. Physical activity and risk of coronary heart disease and stroke in older adults. The Cardiovascular Health Study. Circulation 2016, 133, 147-155. [CrossRef] [PubMed]

73. Lacey, B.; Golledge, J.; Yeap, B.B.; Lewington, S.; Norman, P.E.; Flicker, L.; Almeida, O.P.; Hankey, G.J. Physical activity and vascular disease in a prospective cohort study of older men: The Health in Men Study (HIMS). BMC Geriatr. 2015, 9, 15-164. [CrossRef] [PubMed]

74. Almeida, O.P.; Khan, K.M.; Hankey, G.J.; Yeap, B.B.; Golledge, J.; Flicker, L. 150 Minutes of vigorous physical activity per week predicts survival and successful aging: A population based 11-year longitudinal study of 12,201 older Australian men. Br. J. Sports Med. 2014, 48, 220-225. [CrossRef]

75. Hamer, M.; de Oliveira, C.; Demakakos, P. Non-exercise physical activity and survival. Am. J. Prev. Med. 2014, 47, 452-460. [CrossRef]

76. Sofi, F.; Valecchi, D.; Bacci, D.; Abbate, R.; Gensini, G.F.; Casini, A.; Macchi, C. Physical activity and risk of cognitive decline: A meta-analysis of prospective studies. J. Intern. Med. 2011, 269, 107-117. [CrossRef]

77. Laurin, D.; Verreauli, R.; Lindsay, J.; MacPherson, K.; Rockwood, K. Physical activity and risk of cognitive impairment and dementia in elderly persons. Arch. Neurol. 2001, 58, 498-504. [CrossRef]

78. Varma, V.R.; Tan, E.J.; Wang, T.; Xue, Q.L.; Fried, L.P.; Seplaki, C.L.; King, A.C.; Seeman, T.E.; Rebok, G.W.; Carlson, M.C. Low-intensity walking activity is associated with better health. J. Appl. Gerontol. 2014, 33, 870-887. [CrossRef]

79. Loprinzi, P.D.; Brosky, J.A. Objectively measured physical activity and balance among US adults. J. Strength Cond. Res. 2014, 28, 2290-2298. [CrossRef]

80. Hillsdon, M.M.; Brunner, E.J.; Guralnik, J.M.; Marmot, M.G. Prospective study of physical activity and physical function in early old age. Am. J. Prev. Med. 2005, 28, 245-250. [CrossRef]

81. Mummery, K.; Schofield, G.; Caperchione, C. Physical activity dose-response effects on mental health status in older adults. Aust. N. Z. J. Public Health 2004, 28, 188-192. [CrossRef] [PubMed]

82. Becofsky, K.; Baruth, M.; Wilcox, S. Physical activity mediates the relationship between program participation and improved mental health in older adults. Public Health 2016, 132, 64-71. [CrossRef] [PubMed] 
83. Gebel, K.; Ding, D.; Chey, T.; Stanatakis, E.; Brown, W.J.; Bauman, A.E. Effect of moderate to vigorous physical activity on all-cause mortality in -age and older Australians. JAMA Intern. Med. 2015, 175, 970-977. [CrossRef] [PubMed]

84. Hupin, D.; Roche, F.; Gremeau, V.; Chatard, J.C.; Oriol, M.; Gaspoz, J.M.; Barthélémy, J.C.; Edouard, P. Even a low-dose of moderate-to-vigorous physical activity reduces mortality by $22 \%$ in adults aged 60 years: A systematic review and meta-analysis. Br. J. Sports Med. 2015, 49, 1262-1267. [CrossRef]

85. Nagai, M.; Kuriyama, S.; Kakizaki, M.; Ohmori-Matsuda, K.; Sone, T.; Hozawa, A.; Kawado, M.; Hashimoto, S.; Tsuji, I. Impact of walking on life expectance and lifetime medical expenditure: The Ohsaki Cohort Study. BMJ Open 2011, 1. [CrossRef]

86. Brown, D.R.; Carroll, D.D.; Workman, L.M.; Carlson, S.A.; Brown, D.W. Physical activity and health-related quality of life: US adults with and without limitations. Qual. Life Res. 2014, 23, 2673-2680. [CrossRef]

87. Heesch, K.C.; van Uffelen, J.G.; van Gellecum, Y.R.; Brown, W.J. Dose-response relationships between physical activity, walking and health-related quality of life in mid-age and older women. J. Epidemiol. Community Health 2012, 66, 670-677. [CrossRef]

88. Renaud, M.; Bherer, L.; Maquestiaux, F. A high level of physical fitness is associated with more efficient response preparation in older adults. J. Gerontol. B Psychol. Sci. Soc. Sci. 2010, 65, 317-322. [CrossRef]

89. Hillman, C.H.; Weiss, E.P.; Hagberg, J.M.; Hatfield, B.D. The relationship of age and cardiovascular fitness to cognitive and motor processes. Psychophysiology 2002, 39, 303-312. [CrossRef]

90. Abourezk, T.; Toole, T. Effect of task complexity on the relationship between physical fitness and reaction time in older women. J. Aging Phys. Act. 1995, 3, 251-260. [CrossRef]

91. Clarkson-Smith, L.; Hartley, A.A. Relationships between physical exercise and cognitive abilities in older adults. Psychol. Aging 1989, 4, 183-189. [CrossRef] [PubMed]

92. Spirduso, W.W. Reaction and movement time as a function of age and physical activity level. J. Gerontol. 1975, 30, 435-440. [CrossRef] [PubMed]

93. Aichberger, M.C.; Busch, M.A.; Reischies, F.M.; Ströhle, A.; Heinz, A.; Rapp, M.A. Effect of physical inactivity on cognitive performance after 2.5 years of follow-up: Longitudinal results from the survey of health, ageing, and retirement (SHARE). GeroPsych 2010, 23, 7-15. [CrossRef]

94. Rikli, R.E.; Edwards, D.J. Effects of a three-year exercise program on motor function and cognitive processing speed in older women. Res. Q. Exerc. Sport 1991, 62, 61-67. [CrossRef] [PubMed]

95. Dustman, R.E.; Ruhling, R.O.; Russell, E.M.; Shearer, D.E.; Bonekat, H.W.; Shigeoka, J.W.; Wood, J.S.; Bradford, D.C. Aerobic exercise training and improved neuropsychological function of older individuals. Neurobiol. Aging 1984, 5, 35-42. [CrossRef]

96. Albinet, C.T.; Boucard, G.; Bouquet, C.A.; Audiffren, M. Increased heart rate variability and executive performance after aerobic training in the elderly. Eur. J. Appl. Physiol. 2010, 109, 617-624. [CrossRef]

97. Kramer, A.F.; Hahn, S.; Cohen, N.J.; Banich, M.T.; McAuley, E.; Harrison, C.R.; Chason, J.; Vakil, E.; Bardell, L.; Boileau, R.A.; et al. Ageing, fitness and neurocognitive function. Nature 1999, 400, 418-419. [CrossRef]

98. Almli, C.R.; Ball, R.H.; Wheeler, M.E. Human fetal and neonatal movement patterns: Gender differences and fetal-to-neonatal continuity. Dev. Psychobiol. 2001, 38, 252-273. [CrossRef]

99. Campbell, D.W.; Eaton, W.O. Sex differences in the activity level of infants. Infant Child Dev. 1999, 8, 1-17. [CrossRef]

100. Goldberg, S.; Lewis, M. Play behaviour in the year-old infant: Early sex differences. Child Dev. 1969, 40, $21-31$. [CrossRef]

101. Hutt, C. Sex differences in human development. Hum. Dev. 1972, 15, 153-170. [CrossRef] [PubMed]

102. Pate, R.R.; McIver, K.; Dowda, M.; Brown, W.H.; Addy, C. Directly observed physical activity levels in preschool children. J. Sch. Health 2008, 78, 438-444. [CrossRef] [PubMed]

103. Trost, S.G.; Pate, R.; Sallis, J.F.; Freedson, P.S.; Taylor, W.C.; Dowda, M.; Sirard, J. Age and gender differences in objectively measured physical activity in youth. Med. Sci. Sports Exerc. 2002, 34, 350-355. [CrossRef] [PubMed]

104. Trost, S.G.; Owen, N.; Bauman, A.E.; Sallis, J.F.; Brown, W. Correlates of adults' participation in physical activity: Review and update. Med. Sci. Sports Exerc. 2002, 34, 1996-2001. [CrossRef]

105. Yeats, B. Women and Physical Activity Gender Impact Assessment 12; Women's Health Victoria: Melbourne, Australia, 2010. 
106. Guthold, R.; Stevens, G.A.; Riley, L.M.; Bull, F.C. Worldwide trends in insufficient physical activity from 2001 to 2016: A pooled analysis of 358 population-based surveys with 1.9 million participants. Lancet Glob. Health 2018, 6, e1077-e1086. [CrossRef]

107. Rhodes, R.E.; Mark, R.S.; Temmel, C.P. Adult sedentary behavior: A systematic review. Am. J. Prev. Med. 2012, 42, e3-e28. [CrossRef]

108. Chalabaev, A.; Sarrazin, P.; Fontayne, P.; Boiché, J.; Clément-Guillotin, C. The influence of sex stereotypes and gender roles on participation and performance in sport and exercise: Review and future directions. Psychol. Sport Exerc. 2013, 14, 136-144. [CrossRef]

109. Edwards, E.; Sackett, S. Psychosocial variables related to why women are less active than men and related health implications. Clin. Med. Insights Women's Health 2016, 9, 47-56. [CrossRef]

110. Bengoechea, E.G.; Spence, J.C.; McGannon, K.R. Gender differences in perceived environmental correlates of physical activity. Int. J. Behav. Nutr. Phys. Act. 2005, 2, 12. [CrossRef]

111. Asztalos, M.; De Bourdeaudhuij, I.; Cardon, G. The relationship between physical activity and mental health varies across activity intensity levels and dimensions of mental health among women and men. Public Health Nutr. 2010, 13, 1207-1214. [CrossRef]

112. Woodcock, J.; Franco, O.H.; Orsini, N.; Roberts, I. Non-vigorous physical activity and all-cause mortality: Systematic review and meta-analysis of cohort studies. Int. J. Epidemiol. 2011, 40, 121-138. [CrossRef] [PubMed]

113. Tanasescu, M.; Leitzmann, M.F.; Rimm, E.B.; Hu, F.B. Physical activity in relation to cardiovascular disease and total mortality among men with type 2 diabetes. Circulation 2003, 107, 2435-2439. [CrossRef] [PubMed]

114. Tanasescu, M.; Leitzmann, M.F.; Rimm, E.B.; Willett, W.C.; Stampfer, M.J.; Hu, F.B. Exercise type and intensity in relation to coronary heart disease in men. JAMA 2002, 288, 1994-2000. [CrossRef] [PubMed]

115. Sattelmair, J.; Pertman, J.; Ding, E.L.; Kohl, H.W.; Haskell, W.; Lee, I.M. Dose response between physical activity and risk of coronary heart disease. Circulation 2011, 124, 789-795. [CrossRef] [PubMed]

116. Bassuk, S.S.; Manson, J.E. Physical activity and cardiovascular disease. Nutr. Metab. Cardiovasc. Dis. 2010, 20, 467-473. [CrossRef]

117. Manson, J.E.; Greenland, P.; LaCroix, A.Z.; Stefanick, M.L.; Mouton, C.P.; Oberman, A.; Perri, M.G.; Sheps, D.S.; Pettinger, M.B.; Siscovick, D.S. Walking compared with vigorous exercise for the prevention of cardiovascular events in women. N. Engl. J. Med. 2002, 347, 716-724. [CrossRef]

118. Lee, I.M.; Rexrode, K.M.; Cook, N.R.; Manson, J.E.; Buring, J.E. Physical activity and coronary heart disease in women: Is "no pain, no gain: Passe? JAMA 2001, 285, 1447-1454. [CrossRef]

119. Hu, F.B.; Sigal, R.J.; Rich-Edwards, J.W.; Colditz, G.A.; Solomon, C.G.; Willett, W.C.; Speizer, F.E.; Manson, J.E. Waking compared with vigorous physical activity and risk of type 2 diabetes in women. JAMA 1999, 282, 1433-1439. [CrossRef]

120. Friedenreich, C.M.; Neilson, H.K.; Lynch, B.M. State of the epidemiological evidence on physical activity and cancer prevention. Eur. J. Cancer 2010, 46, 2593-2604. [CrossRef]

121. Tiggemann, M.; Williamson, $\mathrm{S}$. The effect of exercise on body satisfaction and self-esteem as a function of gender and age. Sex Roles 2000, 43, 119-127. [CrossRef]

122. Lustyk, M.K.; Widman, L.; Paschane, A.A.; Olson, K.C. Physical Activity and Quality of Life: Assessing the Influence of Activity Frequency, Intensity, Volume, and Motives. Behav. Med. 2004, 30, 124-132. [CrossRef] [PubMed]

123. Hu, F.B. Physical activity, sedentary behaviors, and obesity. In Obesity Epidemiology; Hu, F.B., Ed.; Oxford University Press: New York, NY, USA, 2008; pp. 301-319.

124. Jaggers, J.R.; Hand, G.A. Health benefits of exercise for people living with HIV: A review of the literature. Am. J. Lifestyle Med. 2016, 10, 184-192. [CrossRef] [PubMed]

125. Lundgren, J.D.; Battegay, M.; Behrens, G.; De Wit, S.; Guaraldi, G.; Katlama, C.; Martinez, E.; Nair, D.; Powderly, W.G.; Reiss, P.; et al. European AIDS clinical society (EACS) guidelines on the prevention and management of metabolic diseases in HIV. HIV Med. 2008, 9, 72-81. [CrossRef] [PubMed]

126. Friedenreich, C.M. Physical activity and cancer prevention: From observational to intervention research. Cancer Epidemiol. Biomark. Prev. 2001, 10, 287-301.

127. Friedenreich, C.M.; Orenstein, M.R. Physical activity and cancer prevention: Etiologic evidence and biological mechanisms. J. Nutr. 2002, 132, 3456S-3464S. [CrossRef] [PubMed] 
128. Tamakoshi, K.; Tokudome, S.; Kuriki, K.; Takekuma, K.; Toyoshima, H. Epidemiology and primary prevention of colorectal cancer. Gan To Kagaku Ryoho 2001, 28, 146-150. [PubMed]

129. Thune, I.; Furberg, A.S. Physical activity and cancer risk: Dose-response and cancer, all sites and site-specific. Med. Sci. Sports Exerc. 2001, 33, S530-S550. [CrossRef]

130. Shephard, R.J. Exercise in the prevention and treatment of cancer. An update. Sports Med. 1993, 15, 258-280. [CrossRef]

131. Shephard, R.J. Physical activity and cancer. Int. J. Sports Med. 1990, 11, 413-420. [CrossRef]

132. Moore, S.C.; Gierach, G.L.; Schatzkin, A.; Matthews, C.E. Physical activity, sedentary behaviours, and the prevention of endometrial cancer. Br. J. Cancer 2010, 103, 933-938. [CrossRef]

133. Hackam, D.G.; Spence, J.D. Combining multiple approaches for the secondary prevention of vascular events after stroke: A quantitative modeling study. Stroke 2007, 38, 1881-1885. [CrossRef] [PubMed]

134. Sluik, D.; Buijsse, B.; Muckelbauer, R.; Kaaks, R.; Teucher, B.; Tj, A.; Overvad, K.; Amiano, P.; Ardanaz, E.; Bendinelli, B.; et al. Physical activity and mortality in individuals with diabetes mellitus: A prospective study and meta-analysis. Arch. Intern. Med. 2012, 172, 1285-1295. [CrossRef] [PubMed]

135. Garber, C.E.; Blissmer, B.; Deschenes, M.R.; Franklin, B.A.; Lamonte, M.J.; Lee, I.M.; Nieman, D.C.; Swain, D.P. American College of Sports Medicine. American College of Sports Medicine position stand. Quantity and quality of exercise for developing and maintaining cardiorespiratory, musculoskeletal, and neuromotor fitness in apparently healthy adults: Guidance for prescribing exercise. Med. Sci. Sports Exerc. 2011, 43, 1334-1359. [PubMed]

136. Mikkelsen, K.; Stojanovska, L.; Polenakovic, M.; Bosevski, M.; Apostolopoulos, V. Exercise and mental health. Maturitas 2017, 106, 48-56. [CrossRef]

137. Asmundson, G.J.; Fetzner, M.G.; DeBoer, L.B.; Powers, M.B.; Otto, M.W.; Smits, J.A. Let's get physical: A contemporary review of the anxiolytic effects of exercise for anxiety and its disorders. Depress. Anxiety 2013, 30, 362-373. [CrossRef]

138. Warburton, D.E.; Bredin, S.S. Health benefits of physical activity: A systematic review of current systematic reviews. Curr. Opin. Cardiol. 2017, 32, 541-556. [CrossRef]

139. Helgadóttir, B.; Forsell, Y.; Ekblom, Ö. Physical activity patterns of people affected by depressive and anxiety disorders as measured by accelerometers: A cross-sectional study. PLoS ONE 2015, 10, e0115894. [CrossRef]

140. LeBouthillier, D.M.; Asmundson, G.J. The efficacy of aerobic exercise and resistance training as transdiagnostic interventions for anxiety-related disorders and constructs: A randomized controlled trial. J. Anxiety Disord. 2017, 52, 43-52. [CrossRef]

141. Hallgren, M.; Herring, M.P.; Owen, N.; Dunstan, D.; Ekblom, Ö.; Helgadottir, B.; Nakitanda, O.A.; Forsell, Y. Exercise, physical activity, and sedentary behavior in the treatment of depression: Broadening the scientific perspectives and clinical opportunities. Front. Psychiatry 2016, 7, 36. [CrossRef]

142. Abu-Omar, K.; Rutten, A.; Robine, J.M. Self-rated health and physical activity in the European Union. Soz. Prav. 2004, 49, 235-242. [CrossRef]

143. Manderbacka, K. Examining what self-rated health question is understood to mean by respondents. Scand. J. Soc. Med. 1998, 26, 145-153. [CrossRef] [PubMed]

144. Noordstar, J.J.; Van der Net, J.; Jak, S.; Helders, P.J.; Jongmans, M.J. Global self-esteem, perceived athletic competence, and physical activity in children: A longitudinal cohort study. Psychol. Sport Exerc. 2016, 22, 83-90. [CrossRef]

145. Gruber, J. Physical activity and self-esteem development in children: A meta-analysis. In Effects of Physical Activity on Children; Stull, G., Eckern, H., Eds.; Human Kinetics: Champaign, IL, USA, 1986; pp. 330-348.

146. Alfermann, D.; Stoll, O. Effects of physical exercise on self-concept and well-being. Int. J. Sport Psychol. 2000, 31, 47-65.

147. Guinn, B.; Semper, T.; Jorgensen, L. Mexican American female adolescent self-esteem: The effect of body image, exercise behaviour and body fatness. Hispanic J. Behav. Sci. 1997, 19, 517-526. [CrossRef]

148. Calfas, K.J.; Taylor, W.C. Effects of physical activity on psychological variables in adolescents. Pediatric Exerc. Sci. 1994, 6, 406-423. [CrossRef]

149. Sonstroem, R.J.; Harlow, L.L.; Josephs, L. Exercise and self-esteem: Validity of model expansion and exercise associations. J. Sport Exerc. Psychol. 1994, 16, 29-42. [CrossRef]

150. Barton, J.; Griffin, M.; Pretty, J. Exercise-, nature-and socially interactive-based initiatives improve mood and self-esteem in the clinical population. Perspect Public Health 2012, 132, 89-96. [CrossRef] 
151. Legrand, F.D. Effects of exercise on physical self-concept, global self-esteem, and depression in women of low socioeconomic status with elevated depressive symptoms. J. Sport Exerc. 2014, 36, 357-365. [CrossRef]

152. Cañabate, D.; Martínez, G.; Rodríguez, D.; Colomer, J. Analysing Emotions and Social Skills in Physical Education. Sustainability 2018, 10, 1585. [CrossRef]

153. Melzer, D.; Lan, T.Y.; Guralnik, J.M. The predictive validity for mortality of the index of mobility-related limitation-Results from the EPESE Study. Age Ageing 2003, 32, 619-625. [CrossRef]

154. Verbrugge, L.M.; Jette, A.M. The disablement process. Soc. Sci. Med. 1994, 38, 1-14. [CrossRef]

155. Peeters, G.; Lips, P.; Brown, W.J. Changes in physical functioning over 6 years in older women: Effects of sitting time and physical activity. Eur. J. Ageing 2014, 11, 205-212. [CrossRef] [PubMed]

156. Gorman, B.K.; Read, J.G. Gender disparities in adult health: An examination of three measures of morbidity. J. Health Soc. Behav. 2006, 47, 95-110. [CrossRef] [PubMed]

157. Montez, J.K. The socioeconomic origins of physical functioning among older U.S. adults. Adv. Life Course Res. 2013, 18, 244-256. [CrossRef] [PubMed]

158. Meader, N.; King, K.; Moe-Byrne, T.; Wright, K.; Graham, H.; Petticrew, M.; Power, C.; White, M.; Sowden, A.J. A systematic review on the clustering and co-occurrence of multiple risk behaviours. BMC Public Health 2016, 16, 657. [CrossRef] [PubMed]

159. Hurst, L.; Stafford, M.; Cooper, R.; Hardy, R.; Richards, M.; Kuh, D. Lifetime socioeconomic inequalities in physical and cognitive aging. Am. J. Public Health 2013, 103, 1641-1648. [CrossRef] [PubMed]

160. Feng, X.; Astell-Burt, T. Neighborhood socioeconomic circumstances and the co-occurrence of unhealthy lifestyles: Evidence from 206,457 Australians in the 45 and up study. PLoS ONE 2013, 8, e72643. [CrossRef]

161. Strand, B.H.; Cooper, R.; Hardy, R.; Kuh, D.; Guralnik, J. Lifelong socioeconomic position and physical performance in midlife: Results from the British 1946 birth cohort. Eur. J. Epidemiol. 2011, 26, 475-483. [CrossRef]

162. Broese van Groenou, M.I.; Deeg, D.J.; Penninx, B.W. Income differentials in functional disability in old age: Relative risks of onset, recovery, decline, attrition and mortality. Aging Clin. Exp. Res. 2003, 15, 174-183. [CrossRef]

163. Freedman, V.A.; Martin, L.G.; Schoeni, R.F.; Cornman, J.C. Declines in late-life disability: The role of earlyand mid-life factors. Soc. Sci. Med. 2008, 66, 1588-1602. [CrossRef]

164. Bernaards, C.M.; Twisk, J.W.; Van Mechelen, W.; Snel, J.; Kemper, H.C. A longitudinal study on smoking in relationship to fitness and heart rate response. Med. Sci. Sports Exerc. 2003, 35, 793-800. [CrossRef] [PubMed]

165. Leyk, D.; Ruther, T.; Witzki, A.; Sievert, A.; Moedl, A.; Blettner, M.; Hackfort, D.; Löllgen, H. Physical fitness, weight, smoking, and exercise patterns in young adults. Dtsch. Arztebl. Int. 2012, 109, 737-745. [CrossRef] [PubMed]

166. Rapuri, P.B.; Gallagher, J.C.; Smith, L.M. Smoking is a risk factor for decreased physical performance in elderly women. J. Gerontol. A Biol. Sci. Med. Sci. 2007, 62, 93-100. [CrossRef] [PubMed]

167. Strand, B.H.; Mishra, G.; Kuh, D.; Guralnik, J.M.; Patel, K.V. Smoking history and physical performance in midlife: Results from the British 1946 birth cohort. J. Gerontol. A Biol. Sci. Med. Sci. 2011, 66, 142-149. [CrossRef]

168. Maraldi, C.; Harris, T.B.; Newman, A.B.; Kritchevsky, S.B.; Pahor, M.; Koster, A.; Satterfield, S.; Ayonayon, H.N.; Fellin, R.; Volpato, S. Moderate alcohol intake and risk of functional decline: The health, aging, and body composition study. J. Am. Geriatr. Soc. 2009, 57, 1767-1775. [CrossRef]

169. O'Keefe, J.H.; Bhatti, S.K.; Bajwa, A.; DiNicolantonio, J.J.; Lavie, C.J. Alcohol and cardiovascular health: The dose makes the poison ... or the remedy. Mayo Clin. Proc. 2014, 89, 382-393. [CrossRef]

170. Lafortune, L.; Martin, S.; Kelly, S.; Kuhn, I.; Remes, O.; Cowan, A.; Brayne, C. Behavioural risk factors in mid-life associated with successful ageing, disability, dementia and frailty in later life: A rapid systematic review. PLoS ONE 2016, 11, e0144405. [CrossRef]

(C) 2020 by the author. Licensee MDPI, Basel, Switzerland. This article is an open access article distributed under the terms and conditions of the Creative Commons Attribution (CC BY) license (http://creativecommons.org/licenses/by/4.0/). 